

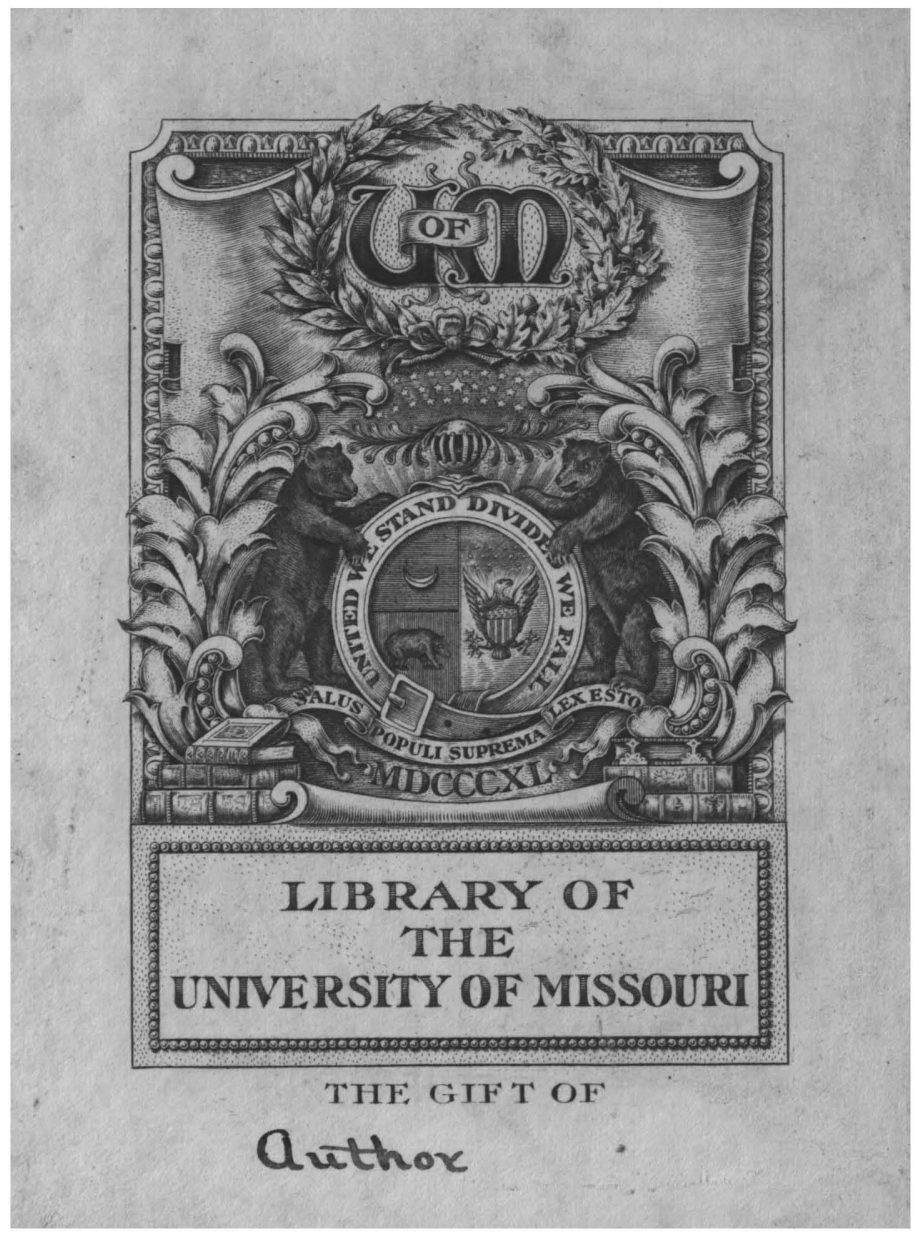

This Thesis Has Been

MICROFILMED

Negative No. T- $\quad \$ 75$

Form 26 








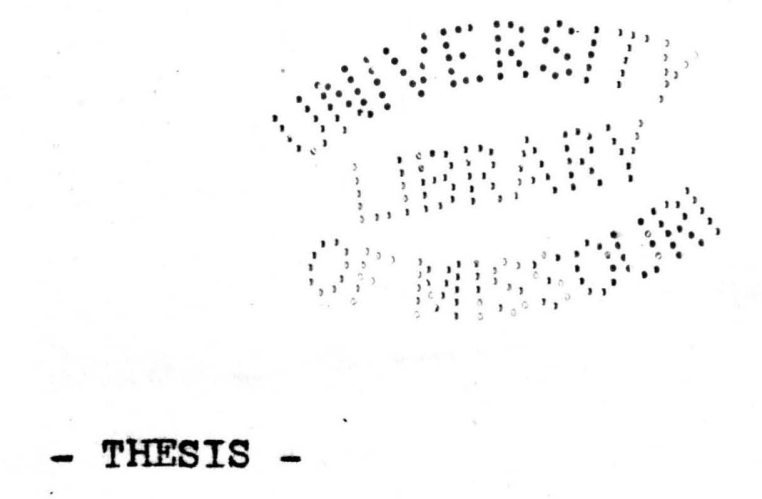

\section{Development of the Glochidium into the Miniature Museel.}

- MARY FITCH -

Submitted to the Faculty of the Graduate Department of the UNIVERSITY of MISSOURT

in partial fulfillment of the requirements for the Degree of MASTER of ARTS.

- JUNE 1906 - 

$378.7 M 71$

$X F 554$

- Development of the Glochldium

into the

Miniature Mussel-

Method of Preparing Material.

A sexually mature mussel was opened and one of the outer gilis,messuring $8 \mathrm{~m} . \mathrm{m}$. at its basal portion, was removed. This was out into small pieces and placed in a dish of fresh water, after which they were shaken with a pair of forceps to free them of the glochidia. It was sometimes possible to peel off the outer covering of the gill and thus expose the glochidia. If the glochidia did not fall out in masses by shaking, they were washed out with a pipette. The glochidia clung together quite tenacoously but by washing them thoroughly with a pipette, they soon fell apart. When the glochidial masses were examined closely with a microscope,they were found to be held together by a thick mucous and not by threads. The mucous seemed to be slightly granular and very resistant to the diluting effect of the water. For this reason, mucous atds glochidia in becoming attached to the fin,for when one of a mass becomes attached it drows a long string of glochidia with it. By the motion of the fin and by the currents of water,they might be lashed up on other 



$$
-2-
$$

fins and thus get attached. If the glochidia were not surrounded by this mucous they would fall to the bottom of the stream and only those fish that stryed close to the bottom would become infected.

The glochidia, when first plroed in the water, were quite active in opening and closing the two valves of the shell. After a period of ten days or tro weeks,it was necessary to subject them to a mechanical or chemical stimulus. An agitation of the water or a sudden jarring of the vessel stimulated them to make a few snapping movements of the valves, as did also a small amount of the killing fluid or a little chloral hydrate.

When one wishes to keep the glochidia for a period of time,it is well to wash them thoroughly, making sure that the most of the mucous has been removed, and to take out all small particles of the gill. It is then well to change the water several times before transferring pemanently. By taking these preoautions,it is possible to keep glochidia for two or more weeks.

In preparing material for future use, the glochidia were stupified in chloral hydrate and killed in sublimate acetic solution. This material was used to study the structure of the glochidium. 

- The strueture of the Glochidium -

The structure of the gloohidium after leaving the gill of the clam was observed in symphynota complanata. whole mounts were prepared and stained in Borax Carmine and Lyon's Blue as this stain seemed to give the best differentiation of the tissue. Sections, cut 4 micra thick, were stained in Borax Carmine and Lyon's Blue, and Iron Haematoxylin and saurefuchsin.

The two valves of this glochidium were almost right-angled triangles in shape, as shown by Figure $I$, Plate I, and were joined together by their bases at the hinge 11ne. The anterior margins of the valves had a greater curve than the postertor. The outer surface of the shell was divided into irregular areas by numerous ridges in the cutioular covering.

In sections stained with Borax Carmine,the shell appeared as though it were composed of a number of small plates, while in the sections stained with Iron Haematoxylin,the shell appeared irregular in thickness due to the ridges on the outside. This plate-like appearance might be caused by some fault in the technique. At the apex of each valve were the large hooks covered with 

several rows of fine,tooth-like projections, which the glochidium uses in fastening itself to its host. They seemed to be just a thiokening of the cuticular covering. In none of the specimens studied was it possible to distinguish any kind of a hinge fastening for the hooks, but inotead they seemed to be just a continuation of the outer cuticular covering.

The two valves were spoon-shaped and were joined together by a strong,internal ligament:. They were lined throughout with pavement epithelium which was composed of Irregrlar, hexagonal cells. The adductor muscle occupied the greater part of the anterior portion of the glochidium and over this muscle the pavement cells were very indefinite as they formed only a thin layer. It was in this that only five or six nuolel could be made out. The other pavement cells were larger,the cell walls and nuclei being well differentlated with the Borax Carmine and Lyon's Blue stain. These cells are quite granular and the stain seemed to show that theae granules were of two different kinds, for with Iron Haematoxylin and saurefuchsin those in the lower part of the cell took the Haematoxylin and those in the upper part the saurefuchsin. This seemed 



\section{$-5-$}

to indicate that there was a difference in their chemical nature. This could not, however, be determined without a series of experiments. With Borax Carmine and Lyon's Blue six dẹeply staining cells were noticed, one in each angle of the valves. These cells were quite large and in specimens stained with Haematoxylin and Saurefuchsin seemed to contain more of the deeply staining granules than the other pavement cells. The symphynota studied had no thread gland and, as this is considered as an excreting organ,it might be possible that these cells served the same purpose as the thread gland.

There was noticed in the whole mounts, posterior to the adductor muscle and on either side of the hinge line,two deeply staining areas, the lateral pits. They were sac-like invaginations that extended anteriorly and had their openings posteriorly. These pits are ectodermal in origin.

Anterior to each lateral pit was a disc-like plate which,in Anodonta,formed a single plate,the oral plate. These plates are thought to give rise to the esophagus the same as the oral plate in Anodonta. In a 

symmetrically developed glochidium,there was a horse shoe or oval mass of cells that lay between the lateral pits and extended slightiy anteriorly between the parts of the oral plate. This was the endodermal sac which showed quite distinctly in cross section,-Figurell,Plate I. Between the lateral pits and the shell were the masses of mesoderm, which, at this early stage, did not show very distinctiy.

A pair of sensory organs were between the parts of the oral plate and the lateral pits,but at times they were found just on the edge. Beneath each hook was a group of three sensory organs which were arranged almost in a straight line in symphynota. In Anodonta these sensory organs were arranged in a triangular form. The position of the hook sensory organs could be made out in the surface view of specimens stained in Borax Carmine and Lyon's Blue. They arose from the narrow strip of cells projecting outwards from the points of the hooks shown in Figure 1,Plate I, and were usually about in line with the sensory organs by the lateral pits. The staining quality of these cells was different from that of the pavement cells but similar to that of the lateral pits. In oross sections, it was found that these organs arose from large cells which possessed large nuclei lying near to the 

rounded basal portion of the cell. The sensory cells possessed long filaments which were intra-cellular and had their origin olose to the nucleus. The nuclear membrane at this point in most of the cells was not distinct. It is thought that these sensory cells are in some way connected with the adductor musele and by their stimulation cause it to contract. It was not possible in any preparations to make out a connection of the sensory organs with the adductor muscle.

This was the stage of development of the glochidium, symphynota complanata, when it left the gill of the mussel. Some irregulartities mere notioed in this development, as the cells in some specimens in the region of the lateral pits were not organized, but scattered irregularly throughout this region. 

Infection and Fncystment of the Glochidium.

In the laboratory, Perch and Minnows seemed to be well adapted for infection purposes, Perch being used in this case. The glochidia were thoroughly washed to separate them before putting in the fish. After placing the fish in the dish, the glochidia were kept well mixed with the water, thus making it possible for a greater number to become attached to the fins, otherwise only the ventral fins would be liable to be infected. The agitation of the water also made the glochlala more active. When the fish were first placed in the dish containing the glochidia,they swam around quite actively but at the end of five or more minutes,many were noticed to hold out the operoula and * vigorously shake the anterior part of the body. The gills of some of these fish were aftermards examined and found to have a great many glochidia attached to them. This goes to show that the shaking was due to the irritation. After a period of fifteen minutes or more, the fish were removed to a tank of water in which they were kept during the further development of the glochidium.

The attaching of the glochidia to the surface of the fins and gills caused an irritation which in turn stimulated the cells in this region to multiply rapidly. From all indications this is an amitotic division. The 

edges of the fins seemed to be better adapted to the attachment of the glochidia than the surface and it was here that the greater number were found attached. The tissue which developed around the glochidia attached to the edge of the fin, seemed to form faster at the sides, and in most specimens, at the end of twenty-four hours, it

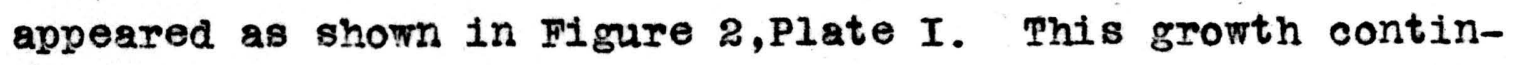
ued so that at the end of thirty-six hours the majority of the glochidia were encysted.

The eysts thickened so that at the end of forty-eight hours (Figure 6, Plate I) the oyst had reached its maximum. Glochidia that attached to the surface of the fin,usually fell over on one side and the tissue grew up in a roll around them. (Figure ${ }^{6}$, Plate I) It always took these specimens longer to encyst, for in Figure 4,Plate I, the glochidium, forty-eight hours after infection, was not entirely encysted. Figure 6,Plate $I$, seemed to be an exception to the mule as the glochidium here still retained its upright position. 



\section{$-10-$ \\ Development of the Glochidium}

The development of the glochidium was observed in Anodonta by the use of whole mounts, longitudinal and transverse sections. For the whole mounts the specimens mere dissected from the preserved fins and stained in Alum Cochineal. The longitudinal sections were eut 15 micra thick and the transverse sections 6 micra thick. Both were stained rith Haem. Alum.

After the glochidium had been on the fish a period of three and one half hours, the only noticeable difference ras a slight enlargement of the endodermal sac. At its antarior part it seemed to have grown ventrally slightly. If the sensory organs were present at this time they were pressed so closely against the tissue of the fin that it ras impossible to make them out.

Fighteen hours after attachment the fundament of the esophagus was formed up to the gut cavity, which had grown slightly anteriorly, but the greater growth seemed to be posterior. The gut anteriorly was broad and much flat tened.

The lateral pits (Ifigure 13,Plate I ) had opened out at the end of twenty-four hours, had grown domnwards and posteriorly, forming the beginning of the mantle. 



$$
-11-
$$

A groove was noticed extending posteriorly from the mouth and on either side of it a ridge was developed. These ridges later grew together to form the anterior part of the foot.

The fin tissue slowly disintegrates, the cells at the edge of the fin appeared to fall apart and float in the space between the two valves. While this was going on, the ectoderm from the lateral pits was pushing the pavenent cells downwards so that they projected out into the space between the valves. These same cells appearedat times to throw out pseudopodia-like processes which later became quite granular in appearance. These cells are thought by SCHIERHOLZ and FAUSSEK to take up nourishment and to function as nurse cells.

After the glochidium has been on the fish for forty-eight hours,marked changes in the digestive system were noticed. The stomodaeum and proctodaeum were both well differentiated. In some specimens the anterior part of the gill showed the beginning of the liver diverticula. The ectoderm on either side of the mouth began to thicken, and in some,to show constrictions preparatory to the formation of the cerebral ganglia. Just anterior to the proctodaeum and on either side of the median plane,a slight invagination and thickening of the ectoderm were 

noticed from which the visceral ganglia are budded off. It was sometimes difficult to differentiate these ganglia from the mesodermal tissues in this region.

The digestive tract continued to grow anteriorly pressing against the posterior part of the adductor muscle, so that by the sixth day this muscle, in some specimens, began to show signs of decay. This was first noticed by the clouded appearance of the muscle cells and also in the irregularity of their form. It seemed possible that a part of the disintegration was due to the pressure exerted by the digestive canal. If this had no effect, why did it not show signs of disintegration in the other parts ? In Figure 2 , Plate II, the muscle appears normal.

The rldges (Figure 4,Plate II) that later help

to form the foot had grown so that they appeared as papillae at this stage and,from the groove was budded off at this time, or earlier,the pedal ganglia.

The visceral ganglia (Figure 6,Plate II ) were definitely formed by this time. The walls of the lateral pits began to thicken (Figure 5,Plate II) preparatory to the formation of the gills. The ectoderm also extended posteriorly to form the mantle, while in the anterior portion the mantle had made its appearance. It might have had its origin by the anterior and dorsal growth of the cells beneath 

the hooks. By the ninth day the glochidium has begun to assume such a form that the important organs could be made out quite readily. The digestive tract from now on made its greatest growth as to size and complexity of the organs. The liver divertioula were broad anteriorly while posteriorIy they were narrow sac-like outgrowths of the stomach portion of the digestive tract, their openings being narrow and slittike. The adductor muscle continued to decay, but in the anterior part itwas still intact. The gill primordia now appeared as papilla projecting out into the space between the two valves.

The two ridges,previously mentioned, separated posterior to the pedal ganglia and there grew down between them a conical projection. These ridges fade out entirely a few micra anterior to the anus. The fin tissue had entirely disappeared but in some glochidia small remnants were found. The nurse cells now appeared quite granular due, no doubt, to the stored up food.

By the twelfth day the liver lobes had grown larger and the stomach made a turn ventrally. It was at this point that a constriction was made dividing it from the intestine, which extended posteriorly as a narrow tube. The adductor muscle had now entirely disintegrated,the cells shrinking up into somewhat spherical, dark staining masses. These seemed to migrate a little and some, 

it was thought, were taken up by the nurse cells. In no case was it evident that these broken down cells migrated to the posterior part of the body and there gave rise to the posterior adductor muscle which made its appearance on or before the twelfth day. The posterior adductor muscle originated from the mesodermal tissue which was anterior to the anal opening and posterior to the visceral ganglia. The groove in the sole of the foot disappeared entirely with the exception of the place where the conical shaped outgrowth protmuded. At this point (Figure 11, Plate II) there was an invagination,or perhaps the tissue on all sides grew down leaving an opening,- the byssus gland. The whole foot had grown larger, rounding out both anteriorly and posteriorly (Figures 10 and 12, Plate II). The gilis had grown longer so that they now extended below the foot.

Grooves appeared on or before the eighteenth day, which definitely marked off the foot regtion from the visceral region. The ciliated epithelium on the foot now became quite noticeable. Not a trace of the original stmacture of the adductor muscle remained, but as yet many of the broken down cells still persistedin the old position. The anterior adductor muscle had appeared by the twenty-first day and the posterior adductor musola had now gromn to be quite a size. The mesodermal cells at the 

posterior and at the sides of the body had formed a more or less cylindrical body which,in places, showed a lumen. This was traced in the sections and appeared to slant anteriorly, having an opening between the gill and the foot. At times it was very difficult to distinguish this tissue from the ganglia and still later in the preparation, it was not posstble to differentiate the tissue. This might have been the kidney, but observations mould have to be made on many other sections before determining this.

The gills at first only possessed one lobe,later another was formed posterior to this one and now at this time there were three,each time one being added posteriorly. They had grown longer so that now they extended underneath the foot which had become wedge-shaped posteriorly (Figures 5,Plate III). The byssus gland was deeper and narrower. The liver, which was now quite large, had become perforated with tubes,there being a central one with branches from it. The edge of the mantle had been completely formed and was quite swollen as was found in the mature miussel. The nurse cells were now being crowded from all sides into an area which was around the adductor muscle and the anterior part of the foot (Figures 2,3 , and 4 ,Plate III) In some specimens there appeared about the 

twenty-eighth day a lumen on either side of the intestine. There were a few cells around the lumen but no well-defined wall as was notioed in the other organs. On the fortysecond day the lumen extended underneath the intestine and up on the sides to the position where the two were noticed at first. Intermediate stages were not ascessible hence the development of this space could not be followed. Fiftytwo days later the open space entirely surrounded the intestine and seemed to project outwards on either side towards the gills. This was undoubtedly the heart but whether it had any connection with the cylindrical bodies previously mentioned, it would be necessary to study a number of stages.

The anterior and postertor retractor muscles (FIgures 4 and 5,Plate III), developed about the trenty-ninth day, but the anterior must have made its appearance earlier as it seemed to be better developed. The flochidium had now all of the important muscles of the adult clam and it seemed possible that they could be used to open and close the shell, and this pressure against the oyst might tend to rupture it. A fow cysts rere notioed to be muptured but the cause could not be determined. In a forty-nine day stage of another series, which was planted at approximately the same time, the general body stmucture was found to be about the 

same. There was quite a variation noticed all along in the development of the glochldium, but the most important development takes place during the first twenty days or so, anyway until after the retractor muscle had been formed. Some specimens of the miusselwere examined after they had been off the fish six days, but in no specimen was a definite supra branohial chamber formed. One did show a one-celled layer under the posterior part of the foot which seemed to have been formed by the delamination of the tisare in this region. The palps were budding off on either side of the mouth. The otolith on either side of the podal ganglia also showed up well at this stage. The miniature musselwas now able to perform all the activities characteristic of the adult.

\section{- Reviews -}

\section{SCHIFRHOIZ (1889) in his article entitled}

"Ueber die Entwicklung der Unionidae" gives quite a complete description of the development of the Foropean mussel, Anodonta piscinalis. In it he takes great care to observe the time at which certain organs make their appearance. only a brief mention will be made of the development of 

some of the organs which differ slightly or are not observed in symphynota complanata.

The first indication of the foot is a depressIon, which later swells up into an oval outgrowth. No mention is made of a groove in the anterior parts of the foot; the ganglia are observed as large cells on the side of the foot. These later sink into the tissue and divide into a chain of four cells. SCFMIDT and SCHIERHOLTZ both consider that the midimentary byssus glands originate from the outicle just above the pedal ganglia forming pits which are spoken of as "flowing together" and giving rise to the groove in the sole of the foot. Oval masses of mesoderm were noticed in the region of the gills, which he termed gill ganglia. When SCFMIDT made the discovery of the visceral ganglia,SCFIERHOLTZ made another careful study of hio material and found that the bodies which he had ldentified as ganglia were not ganglia. The visceral ganglia were found, but he considered that their origin from the ectoderm was still an open question.

The nervous system in general is described in great detail, even to the formation of the branches from the oomntssures. The posterior part of the adductor muscle was 

noticed to shrink, but this was not observed in the anterior part. This led him to conclude that the anterior adductor muscle has its origin from the anterior part of the adductor muscle.

The most important thing brought out by V.FAUSSFK in his paper (1895) "Ueber den Parastitismus der Anodonta-Larven in der Fischhaut", is the nourishment of the glochidium. He considers the pavement cells (embryonic mantle) as the nourishing organ of the embryo. After the formation of the edge of the mantle appears,these cells are crowded together making them appear as fungus bodies. By thts time the stomodaeum and proctodaeum are formed so that nourishment can be taken by the digestive tract, as well as in an intracellular manner. He speaks of the large pavement. cells of the ectoderm as having a function similar to that of the ectodern in the mammalian placenta, i.e. the taking up of nourishment.

In a later paper FAUSSEK says that the accumulation of lymph around the glochldium often causes the tissue of the cyst to become reticular so that more leucocytes find their way into the oyst. In the case of the glochidium he considers the accumulation of the leucocytes as merely a cytological effect, and thinks that real phagocytes playsonly a subordinate role in the later stages of such glochidia as are killed by the tissue of the figh. 



\section{LITERATURE}

I. BRAWN,M. - - Postembryonale Entwicklung von Anodonta Zool. Anz . Jahrg. 1878.

II. BRAWN,M. - - Post embryonale Entwioklung der Najaden. Nachrichtsbl Deutschen Malakozool. Gesellsch.Frankfurt a.m.Jahrg.XIX. 1887.

III. FAUSSEJ,V. - Ueber den Parasitismus der AnodontaLarven in der Fischhaut. Biologisches Centralblatt 1895.

IV. FAUSSEK, V. - Ueber den Parasitismus der AnodontaLarvan.

Verhandlungen des V.Internationalen Zoologen Congresses Berlin 1901.

V. KORSCHELTHEIDER, - - Text Book of Bmbryology.

VI. KORSCHELTHWIDER, - Stmuktur der Anodonta-Larven Lehrbuch der Entwicklungs-geschiste. Li eferung III.

VII. LILLIE,F.K. - The Embryology of the Unionidae. Journal of Morphology Vol.X. 1895. VIII. MEISSENHEIMER, J,- Die Entwicklungs von Herz Perikard Niere und Geintalzelben bei cyclas im Verhaltriz zu den ubrigen Mollusken. Zeit of Wiss. Zool. $69 \mathrm{Bd}$. 

IX. SCHIERHOLXZ, - Veber die Entwicklung Unionden. Denschr.k. Akad. wiss. Wien.Math. Nat. Cl. ,55 Bd., 1889 .

X. SCHMIDT,F. - Beitrag zur Kenntniss der postembryonalen Entwicklung der Najaden. Archiv.fur Natur-geschichte Jahrg. $51,1885$. 



\section{$-22-$ \\ EXPLANATION OF PLATES}

PLATE I

Figure 1. Embryo of symphynota complanata as it leaves the gill of the Mussel.

Figure 2. Anodonta glochidium 34 hours after attachment to the edge of the fin.

Figure 3. The same 24 hours after attachment to the surface.

Figure 4. Forty-eight hours after attachment to the surface of the fin.

Figure 5. Glochidium 48 hours after attachment to the edge of the fin.

Figure 6. Glochidium in an upright position 48 hours after attachment to the surface of the fin.

Figure 7. View showing fin 24 hours after infecting.

Figure 8. View showing fin 48 hours after infecting.

Figure 9. Side of Glochidium showing markings of the shell.

Figure 10.Section of symphynota complanata showing lateral pits and one group of sensory organs.

Figure 11.Section showing endodermal sac.

Figure 12.Sensory cell showing nucleus and intracellular filaments.

Figure 13. Section of Anodonta showing the lateral pits at the end of 24 hours. 



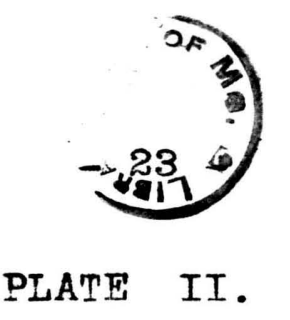

Figure 1. Diagram of Anodonta glochidium six days after attachment.

Figure 2. Section of Fig.l through A B showing adductor muscle.

Figure 3. Section of Fig.I through C D showing mouth opening.

Figure 4. Section of Fig.l through E F showing groove and ridges.

Figure 5. Section of Fig.l through H I showing gill swellings.

Figure 6. Section of FIg.I through $J \mathrm{~K}$ showing formation of visceral ganglia.

Figure 7. Diagram of glochidium twelve days after attachment.

Figure 8. Section of Fig.7 through A B showing anterior part of disintegrating adouctor muscle.

Figure 9. Section of Fig.? through C D showing posterior part of adductor muscle and the cerebral ganglia. Figure 10. Section of Fig. 7 through E.F showing gut cavity with the liver diverticula,pedal ganglia, rounded foot, eage of mantle and nurse cells.

Figure 11. Section of Fig.7 through H I showing the byssus gland, and posterior part of gut cavity. Figure 12. Section of Fig.7 through $J \mathrm{~K}$ showing intestine, gills, and mantie. 



\section{PLATE III.}

Figure 1. Diagram of glochidium twenty-eight days after attachment.

Figure 2. section of same through A B showing anterior adductor muscle, nurse cells, and mantle.

Figure 3. Section of same through C D showing cerebral ganglia,palp of fundament, anterior part of foot., edge of mantle, and nurse cells.

Figure 4. Section of same through $E F$ showing anterior retractor muscle, and foot.

Figure V. Section of same through H I cut at an angle showing one of the posterior retractor muscles, intestine and gills. 


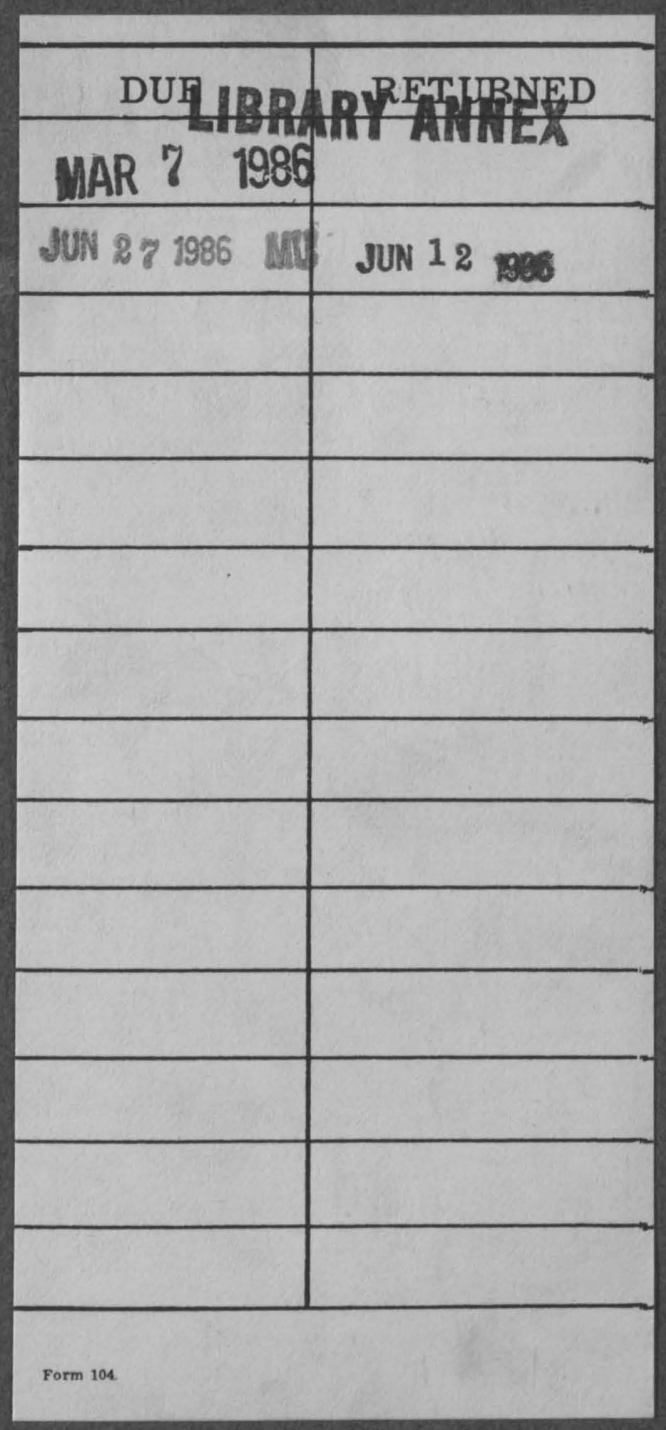




\section{ReGsus: \\ Noy 80.190 \\ Untwe $0=100$}

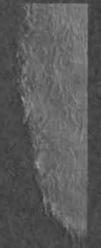

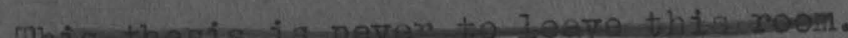
whe thar-iseit bo be chekeed aut orernight.

\section{LIBRARY ANIHEX}


